УДК 631.3

\title{
СОВЕРШЕНСТВОВАНИЕ РАБОЧИХ ОРГАНОВ ВИНОГРАДОЧЕКАНОЧНОЙ МАШИНЫ
}

\section{Горобей Василий Петрович}

д.Т.Н., снс

ФГБНУН «ВННИИВиВ «Магарач» РАН

\begin{abstract}
Аннотация: С учетом агротехнических требований к процессу удаления лозы винограда в осенне-зимний период и побегов в вегетационный проанализированы технические решения для механизации технологического процесса. Обоснованы условия для расчета параметров скользящего резания, как одного из важных параметров повышающих чистоту среза и понижающих энергоемкость агротехнического приема. Результаты проведенных исследований позволят ускорить моделирование и изготовление рабочих органов чеканочных машин с инновационными техническими решениями для экспериментального апробирования в лабораторных и полевых условиях.

Ключевые слова: виноградник, возделывание, механизация, побеги, лоза, обрезка, чеканка, ножи, параметры, скольжение, расчет.
\end{abstract}

\section{IMPROVEMENT OF THE WORKING BODIES OF THE GRAPE-ROLLING MACHINE}

\section{Gorobey Vasily Petrovich}

Abstract: Taking into account the agrotechnical requirements for the process of removing grape vines in the autumn-winter period and shoots in the growing season, technical solutions for the mechanization of the technological process are analyzed. The conditions for calculating the parameters of sliding cutting, as one of the important parameters that increase the purity of the cut and reduce the energy intensity of the agricultural technique, are justified. The results of the conducted research will speed up the modeling and manufacturing of working bodies of coining machines with innovative technical solutions for experimental testing in laboratory and field conditions.

Key words: vineyard, cultivation, mechanization, shoots, vine, pruning, chasing, knives, parameters, sliding, calculation. 


\section{Одним из важнейших агротехнических приемов выращивания} винограда является подрезка виноградных кустов, который во всех рекомендациях, технологических картах возделывания винограда приводится как обрезка кустов (нормированная, поправочная, осенняя, весенняя и т.п.) [1, c. 25]. Обрезка и формирование кустов являются основой системы культуры виноградного растения. Ежегодно, удаляя часть древесины, можно управлять процессами роста и плодоношения куста и лучше приспосабливать растение к условиям возделывания. В основе теории обрезки лежит биологический закон единства между живым организмом и средой, а также единства свойств организма, проявляющийся у виноградной лозы между ростом и плодоношением; между надземной частью куста и его корневой системой, между длиной побега и потенциалом генеративных почек, на нем расположенных; между количеством и качеством урожая и др. [2, с. 78]. Обрезка кроны позволяет также придавать форму, удобную для эффективного использования машин при уходе за насаждениями и уборке урожая [3, с. 412]. Обрезка, сгребание из междурядий и вывозка лозы на межклеточные дороги, сволакивание, погрузка и транспортировка к месту сбора определяются технологическими регламентами. Ограниченный срок выполнения этих операций обуславливает применение комплексной механизации и поточную работу агрегатов [4, с. 183]. Для обрезания кустов рекомендуют использовать пневмоагрегаты ПАВ-8А (разработчик АО ГСКБ, г. Кишинев) и АСВ-8 (разработчик ГНУ ВСТИСП, г. Москва). Известно устройство «Грегуар» (Франция) для предобрезки виноградной лозы. В большинстве хозяйств кусты обрезают вручную при помощи инструмента НBO, секаторы и ножи которого затачивают на станке СЗУ-2 [5, с. 48].

Чеканка винограда, как агроприем удаления верхушки виноградных побегов применяется с целью повышения урожайности, улучшения вкусовых качеств ягод, повышения эффективности защитных мер против болезней и вредителей. Она ингибирует вегетативный рост и усиливает питание ягод, положительно влияет на активность камбия и способствует увеличению слоев мягкого и твердого луба побегов, изменяет фитоклимат куста (увеличивает доступ воздуха, света и тепла внутрь кроны). При чеканке удаляется верхушка побегов от 15 до 30 см. Осуществляется вручную с использованием мелкого инвентаря или механизировано с помощью специальных навесных машин [6, c. 408]. Основная цель обрезки молодых кустов - создать правильную форму куста по заданной схеме. В зависимости от сложности принятой формировки, 
от способа ее выделения и силы роста побегов, формирование куста может быть закончено на 3 - 4-й год или несколько позже. В засисимости от возраста кустов и их состояния обрезают от 70 до 95\% годичного прироста [7, с. 227]. Чеканят побеги маточных подвойных лоз для задержки их роста и создания более благоприятных условий для вызревания. При этой операции удаляют три - пять верхних узлов. Чеканят в период естественного замедления роста побегов [8, с. 104].

Основное требование агротехнического характера при обрезке любых растений и, в частности винограда, является чистота среза. Срезы должны быть ровными и гладкими, только при этом условии раны, наносимые растениям, будут наименьшими. Требование производственного характера обеспечение как можно меньших усилий и затрат на процесс одного перерезания [9]. Ряд параметров процесса резания виноградной лозы имеют важное значение. Поэтому некоторые основные тенденции развития конструкций машин для обрезки виноградников сохраняются, в том числе: внедрение рабочих органов, обеспечивающих высокое качество среза виноградной лозы; обеспечение высокой производительности за счет одновременной обрезки одного ряда со всех сторон при чеканке и двух рядов при сплошной осенней подрезке виноградников; тенденция по замене сегментных режущих органов различными по конструкции режущими органами роторного типа[10, с. 13]. Скорость резания при прочих равных условиях определяет качество среза. Срез стеблей сопровождается их разрывом. Поэтому при расчете на прочность деталей режущего аппарата необходимо учитывать усилия, возникающие от натяжения стеблей [11, с. 67]. Диапазон технологически необходимой скорости должен обеспечивать чистый срез с минимальным сопротивлением. Кинематика привода и конструкция режущего аппарата должна быть выбрана таким образом, чтобы скорость ножа в процессе резания была выше технологически необходимой, т.е. $\mathbf{u}>\mathbf{u}_{\mathrm{T}}[12$, c. 127$]$.

Резание ножом обычно сопровождается не только нормальным движением лезвия по направлению разреза, но и вдоль лезвия, скользящим движением. Это скользящее движение играет решающую роль в резании [13, с. 120]. Наличие скольжения уменьшает расход энергии на резание [14, с. 59].

Повышение качества среза виноградного растения действующими инструментом и машинами при уходе за виноградниками является актуальной задачей. 
Для расширения технологических возможностей лезвийной пары рабочего инструмента виноградаря, нами ранее была обоснована форма лезвия режущего ножа для работы с противорезом с использованием процесса скольжения для осенней обрезки виноградной лозы и чеканки побегов винограда различных диаметров в вегетационный период (Патент RU № 178799 Секатор садовый, опубл. 19.04.2018). При этом лезвие режущего ножа выполнено в виде сегмента эксцентрической окружности, геометрические размеры которой определены по формулам: $R=2,35 d, r_{\max }=2,75 d, e=R \cos (\tau)$, $\tau=51-57^{\circ}$, где $R$ - радиус сегмента режущего ножа, $r$ - радиус-вектор эксцентричного круга, $e$ - величина эксцентриситета режущего ножа, $\tau$ - угол между радиус-вектором и касательной к сегменту, а рабочая часть противорежущего ножа выполнена с вырезом длины $l$ и глубины $h$, которые находятся в зависимости от максимального диаметра $d$ перерезаемой ветки $l=$ $0,3 d, h=0,2 d$, расположенным на рабочей части за ограничительным барьерным возвышением на кратчайшем расстоянии $(L)$ от оси шарнира $[15$, c. 23$]$.

Целью исследований является обоснование рабочих органов машины для чеканки побегов винограда, обеспечивающих ровный срез побегов, не разрывая и не размочаливая их тканей в месте среза, при осуществлении технологического процесса со снижением энергозатрат.

Одновременное достижение этих задач возможно при условии, что ножи будут не рубить побеги, а резать их со скольжением. Для этого необходимо, чтобы вдоль всего режущего периметра лезвия ножа угол скольжения был постоянным и большим угла трения побега по лезвию. Поэтому форма лезвия ножа должна быть такой, чтобы угол $\varepsilon_{0}$ между касательной к линии лезвия и перпендикуляром к радиусу-вектору $\rho$, соединяющему данную точку лезвия с осью вращения ножа, был постоянным вдоль всей режущей кромки (рис. 1).

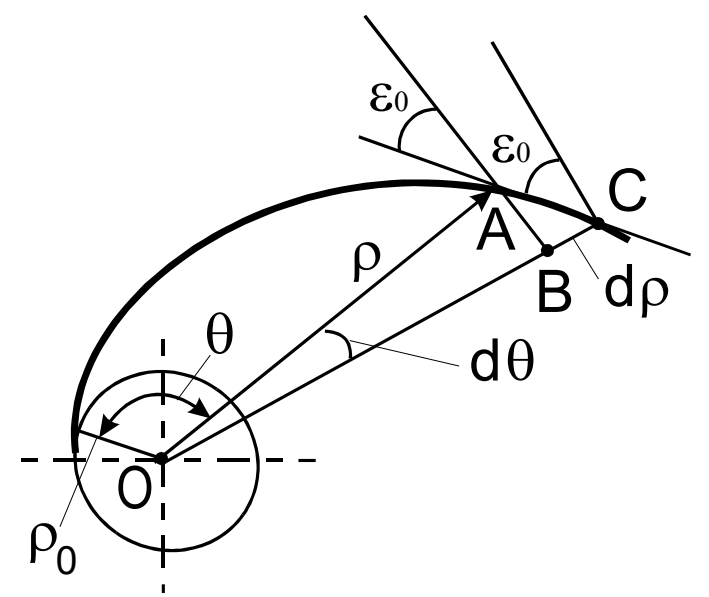

Рис. 1. Эквивалентная схема динамики лезвия ножа при сохранении угла скольжения

99 
Из треугольников $\mathrm{ABC}$ и ОАВ согласно рис. 1 находим:

$\mathrm{OA}=\rho, \mathrm{BC}=d \rho, \mathrm{OC}=\rho+d \rho, \mathrm{AB}=\rho d \theta$,

$$
\operatorname{tg} \varepsilon_{0}=\frac{B C}{A B}=\frac{d \rho}{\rho d \theta} .
$$

Из равенства (1) выразим $d \theta$ :

$$
d \theta=\frac{d \rho}{\rho \operatorname{tg} \varepsilon_{0}} .
$$

Интегрируя уравнение (2), получим:

$$
\theta=\frac{1}{\operatorname{tg} \varepsilon_{0}} \ln \rho+C .
$$

Определим постоянную интегрирования $C$ при начальных условиях $\theta=0, \rho=\rho_{0}$ :

$$
C=-\frac{1}{\operatorname{tg} \varepsilon_{0}} \ln \rho_{0},
$$

тогда из выражения (3) с учётом (4) после преобразований получим:

$$
\theta=\frac{1}{\operatorname{tg} \varepsilon_{0}} \ln \frac{\rho}{\rho_{0}} .
$$

Из выражения (5) получим уравнение линии лезвия ножа:

$$
\rho=\rho_{0} e^{\theta \operatorname{tg} \varepsilon_{0}} .
$$

Для обеспечения скользящего резания необходимо выполнение условия:

$$
\varepsilon_{0} \geq \varphi,
$$

где $\varphi$ - угол трения побега по лезвию.

Тогда, с учётом условия (7), уравнение (6) линии лезвия ножа примет вид:

$$
\rho=\rho_{0} e^{\theta \operatorname{tg} \varphi} .
$$

Полученное выражение является уравнением логарифмической спирали, полюс которой находится на оси вращения ножа, а длина начального радиусвектора $\rho_{0}$ равна половине ширины ножа.

Обоснованы условия для расчета параметров линии лезвия ножа, обеспечивающей постоянство угла скольжения при уходе за виноградниками в осенне-зимний и вегетационный периоды. Результаты проведенных исследований позволят ускорить моделирование и изготовление рабочих 
органов чеканочных машин для экспериментального апробирования в лабораторных и полевых условиях.

\section{Список литературы}

1. Авидзба А.М., Борисенко М.Н., Скориков Н.А., Бейбулатов М.Р., Мишунова Л.А. Проблемные вопросы виноградарства в Республике Крым// Магарач. Виноградарство и виноделие. - 2015. - № 4. - С. 25-26.

2. Фулга И.Г. Основы виноградарства и плодоводства. М.: Колос,1978. - C. 78 .

3. Комаристов В.Е., Дунай Н.Ф. Сельскохозяйственные машины. - 3-е изд. перераб. и доп. - М.: Колос, -1984. - С. 412.

4. Хмелев П.П., Зельцер В.Я., Корючкин А.Е. Механизация виноградарства. - М.: Колос, -1971. - С. 183.

5. Кузнецов Г.Я., Талаш А.И., Беспалов А.Л., Евдокимов А.Б., Колмыков А.Е., Колесников Ф.С. Механизация производственных процессов в виноградарстве существующими и перспективными машинами/Садоводство и виноградарство. - 2014.- № 3. - С.45-48.

6. Энциклопедия виноградарства : в 3-х томах. Гл. ред. А.И. Тимуш. Кишинев: Гл. ред. Молд. Сов. Энциклопедии, - 1987. - Т.3. - С. 408.

7. Книга виноградаря/ Составитель К.П. Скуинь. М.: Сельхозгиз, 1959. - C. 227.

8. Мишуренко А.Г., Красюк М.М. Виноградный питомник. - 4-е изд. перераб. и доп. - М.: Агропромиздат, - 1987. - С. 104.

9. Хилькевич Н.И. Подрезка и формирование кустов винограда. Симферополь. Крымиздат, - 1958. - 63 с.

10. Варламов Г.П., Кротов А.М. Состояние и тенденции развития конструкций машин и приспособлений для ухода за садами, ягодниками и виноградниками/ Отечественный и зарубежный опыт. Серия: Сельскохозяйственные машины, агрегаты и узлы. Вып.3. - М.: ЦНИИТЭ Итракторосельхозмаш, - 1981. - С. 13 с.

11. Иванцов В.И. Скорость резания стеблей в режущем аппарате с двумя подвижными ножами // Конструирование рабочих органов сельскохозяйственных машин. Ростов -на Дону, - 1971.- С. 67.

12. Киртбая Ю.К., Халитов А.Н., Аблин Л.К., Леонтьев П.И. Механизация сельского хозяйства. - М.: Колос, - 1974. - С. 127.

13. Горячкин В.П. Собрание сочинений. Т.3. - 1968. - М.: Колос, -1968. - C. 120-133. 
14. Лучинский Н.Д. Некоторые вопросы земледельческой механики/ Теоретические основы механизации важнейших процессов сельскохозяйственного производства. М.: Труды ВИМ, -1977. т.75.- С. 38-59.

15. Борисенко М.Н., Скориков Н.А., Горобей В.П., Мишунова Л.А., Сафонов А.Ф. Усовершенствование конфигурации лезвийной пары секатора для обрезки виноградных кустов// Магарач. Виноградарство и виноделие. 2018. - № 1. - С. 23-25. 